\title{
A Review of Lobster (Homarus americanus) Landing Trends in the Northwest Atlantic, 1947-86
}

\author{
D. S. Pezzack \\ Department of Fisheries and Oceans, Biological Sciences Branch \\ Halifax Fisheries Research Laboratory, P.O. Box 550 \\ Halifax, Nova Scotia, Canada B3J 2S7
}

\begin{abstract}
The lobster (Homarus americanus) fishery is one of the most important inshore fisheries in eastern Canada, representing $28 \%$ of the total landed value in 1985. Landings along much of the coast dropped to near record lows in the late-1960s and 1970s, but then increased to levels not experienced since 1900. Total landings doubled between 1977 and 1986 and in some areas landings increased tenfold. A review of trends in landings since 1947 shows that the major increases and decreases occurred in all areas, though the timing and magnitude differed. The recent increase in landings began in the mid-1970s in the southern Gulf of St. Lawrence and in 1980 in the cooler areas of the Scotian Shelf and Gulf of Maine. In Maine and Newfoundland they have been stable with 1986 landings near historic means. The increase in landings during the last 10 years is the result of increased recruitment. The recent increases have occurred in a variety of stocks and management regimes, suggesting wide spread environmental factors as the primary cause.
\end{abstract}

\section{Introduction}

The lobster (Homarus americanus) is extensively fished in eastern Canada (Fig. 1), and the inshore fishery is one of the most important in eastern Canada. The fishery represented $28 \%$ of the total Atlantic Canadian landed value in 1985. Variation in lobster abundance can have a major effect on the economy of many communities. Over the last 40 years the fishery went from above average landings in the 1950s, to near record lows during the 1960s and 1970s. The fishery recovered in the late-1970s and total landings doubled between 1977 and 1986, and in some areas landings increased tenfold. The recovery in the 1980s has resulted in the highest landings this century (Fig. 2).

The increased landings of the 1980s have generated interesting questions about what controls recruitment and stock size. This paper reviews the long-term landing trends and hypotheses proposed to explain them.

\section{Materials and Methods}

The lobster fishery in eastern Canada is a trap fishery conducted mainly by inshore fishermen generally fishing in depths less than $40 \mathrm{~m}$ (Duggan, 1985). Offshore, eight licensed boats fish beyond $92 \mathrm{~km}$ from shore (Offshore Fishing District) on the Scotian Shelf and Georges Bank (Pezzack and Duggan, MS 1987). The inshore fishery is managed within Lobster Fishing Areas (LFA; Fig. 1) using trap limits, fishing seasons, and minimum legal carapace length $(C L)$, which are set to fit regional, socioeconomic, biological and climatic conditions.
Annual landing trends were examined for the following geographic locations (Fig. 1, 3): Newfoundland, Quebec, southern Gulf of St. Lawrence (LFA 24-26), northeastern Cape Breton (LFA 27), southeastern Cape Breton (LFA 28-30), eastern shore of Nova Scotia (LFA 31-32), southeastern Nova Scotia (LFA 33), southwestern Nova Scotia (LFA 34), Grand Manan (LFA 38), Bay of Fundy (LFA 35-36), and the States of Maine (data courtesy of $J$. Krouse, Maine Dept. of Marine Resources, USA) and Massachusetts (data courtesy of B. Estrella, Massachusetts Division of Marine Fisheries, USA). Together the areas discussed account for over 95\% of the western Atlantic lobster landings.

Annual landing trends in the fishery are considered good indications of annual lobster recruitment into the fishery. High exploitation rates, which range from 60 to 90\% ( $F=0.9-2.0$; Anthony, 1980; Campbell, 1980; Miller et al., MS 1987) mean that most fisheries depend on newly recruited animals for the bulk of their catch (Ennis, 1986).

Historical landings data (1892-1986) in the present analysis were smoothed using a 3-year moving average that reduced variation resulting from abiotic factors such as weather, short-term variations in effort and variability introduced by use of annual rather than seasonal landings.

Canadian landings were recorded by county between 1892-1946, and by Statistical Districts since 1947. Landings data for each area were normalized with respect to the area mean of 1947-86 to allow 


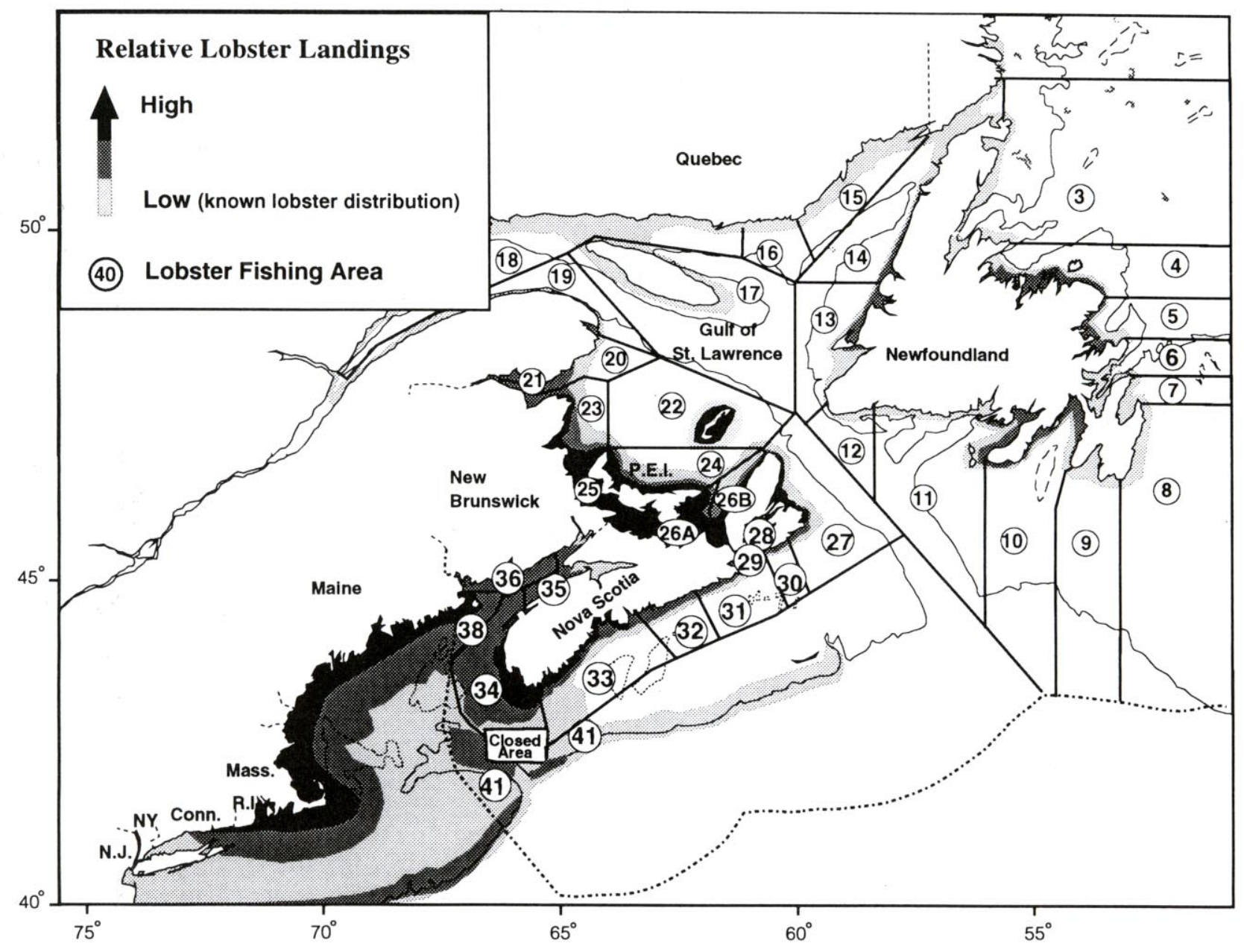

Fig. 1. Map of study area in the Northwest Atlantic showing Lobster Fishing Areas (LFA), known lobster distribution, and relative landings (based on landings data, distribution of lobster fishing and groundfish trawl surveys).

easier comparison of trends between LFA with landings that can differ by a factor of 100 . A normalized catch value of 0.9 represents a catch that was $90 \%$ of the mean and a value of 3.0 represents a catch of $300 \%$ or 3 times the mean.

\section{Results and Discussion}

\section{History of fishery and landing trends to 1946}

In Canada, the commercial lobster fishing began in the mid-1800s (Dow, 1980) and landings have been formally recorded since the 1880s. Canadian landings exceeded 40000 tons annually in the 1880s (total North American landings over 60 000 tons; Ennis and Squires, 1986). Even as landings continued to increase, concern about the future of the industry was expressed because the mean lobster size in the catch was decreasing (Venning, 1873; 1893). Size limits, seasons and a prohibition on landing egg-bearing females were first introduced in the 1890s, but these regulations were not widely adhered to (DeWolf, 1974). In- creased concern resulted in numerous Canadian Government inquiries and studies commissioned between 1887 and 1913 to find the cause of declining catches.

Declining catches in the 1890s led fishermen to adopt the more efficient parlour trap, and the introduction of gasoline motors in the early-1900s allowed fishermen to fish up to three times as many traps per day (DeWolf, 1974). Landings continued to fall, dropping to a low of 12400 tons in 1918 (Fig. 2), and fluctuated between 13000 and 20000 tons in the 1920s. DeWolf (1974) suggested that a small increase in the early-1930s to 22000 tons was due in part to an increase in the number of fishermen because of high unemployment during the early years of the Great Depression. This short-lived recovery occurred in the southern Gulf of St. Lawrence region and along the eastern shore of Nova Scotia and southern Cape Breton, while landings remained low in the Gulf of Maine area. In Newfoundland the lobster fishery was closed for 2 


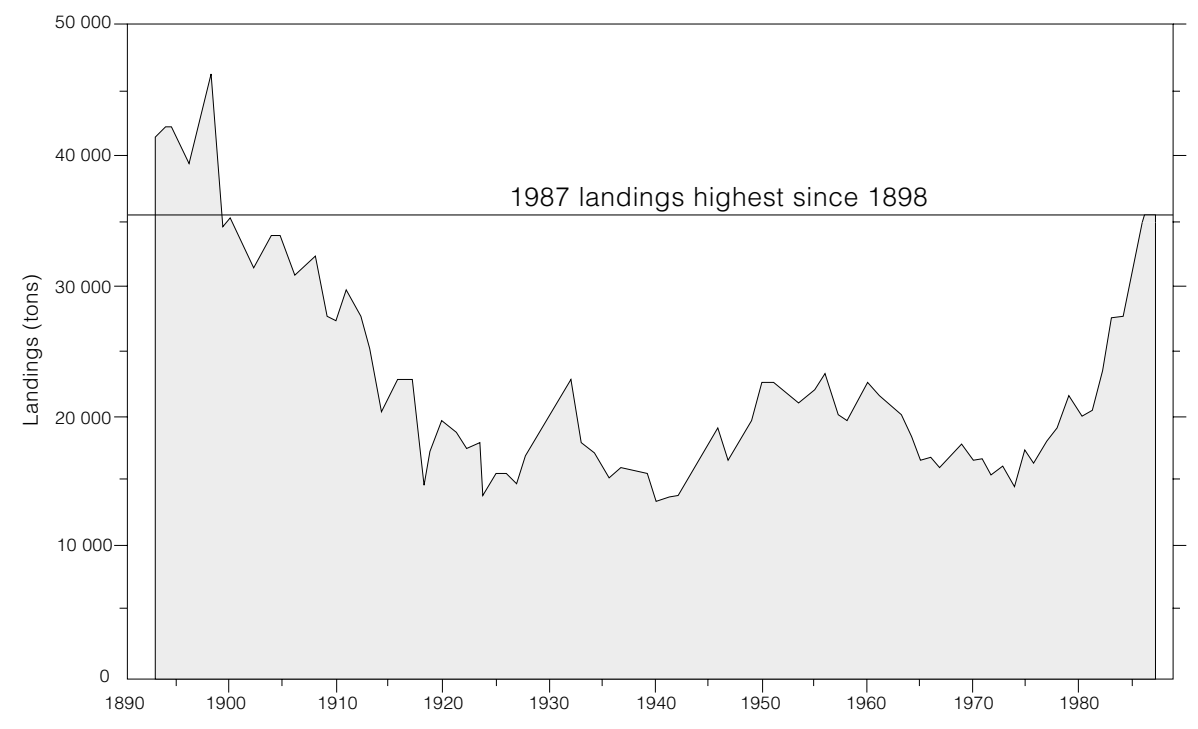

Fig. 2. Total lobster landings reported in eastern Canada during 1893-1987.

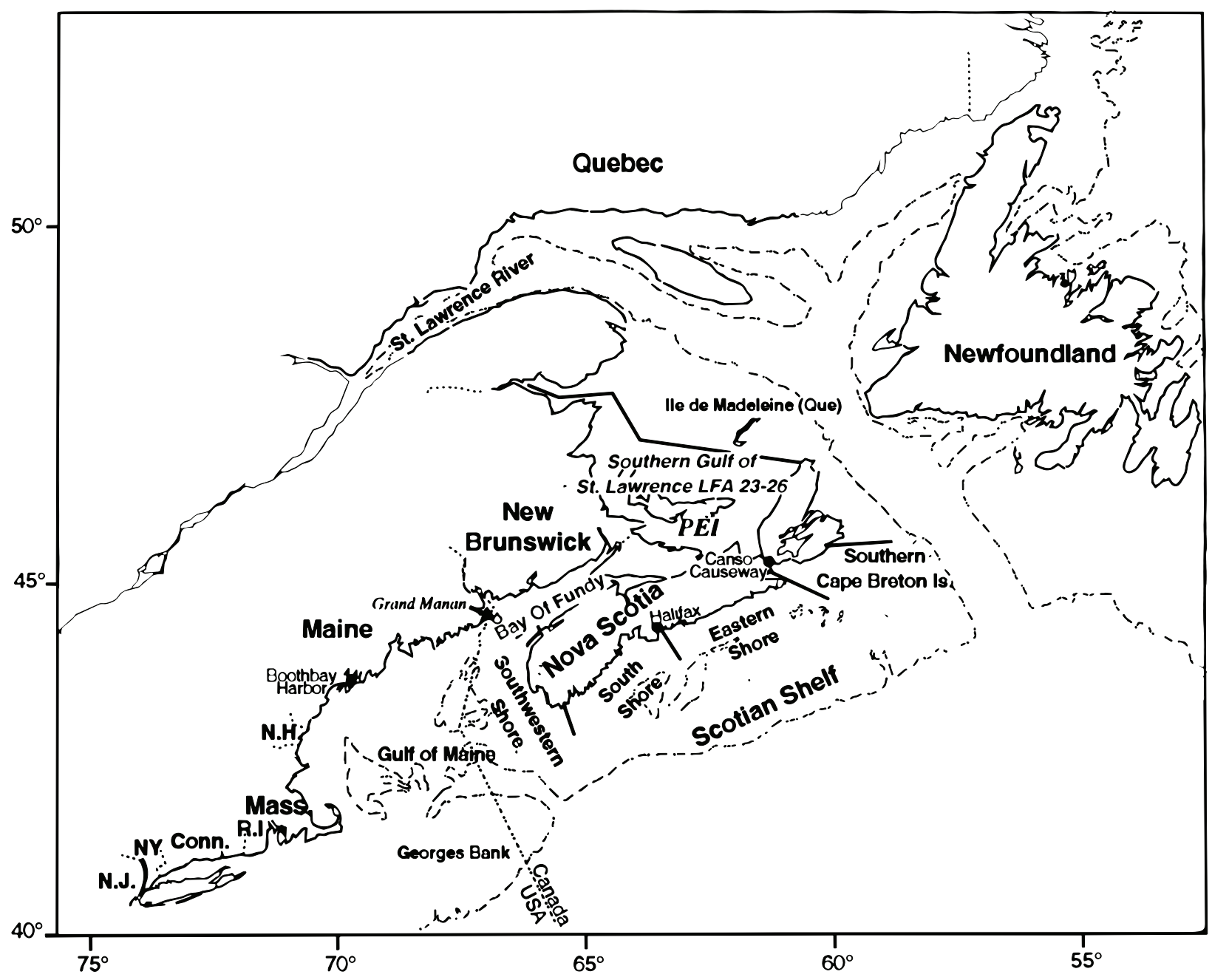

Fig. 3. Map showing place names and areas in Canada and the United States referred to in text. 
years (1925-27) in an attempt to reverse the decline, and landings rebounded to the 1910 levels then remained relatively constant (Fig. 4).

\section{Landing trends 1947-86}

Canadian landings increased between 1940 and 1950, and peaked in 1956 at 23000 tons (Fig. 2). A long period of decline began in the early-1960s and continued into the mid-1970s with lowest landings of 14000 tons in 1974. The decline was greatest along the LFA 31-32 and LFA 24-26 where landings reached record lows (Fig. 4). Maine landings increased in the 1940s and peaked in the mid-1950s, then declined in the 1960 s and early-1970s. How- ever, Maine landings remained over twice as high as during the 1920 s and 1930s.

Landings increased sharply beginning in the late-1970s and early-1980s in the LFA 24-26 and LFA 33, 34, 35 and 36 respectively, reaching levels higher than those of the early part of the century. In 1986, LFA 27 landings were twice the previous high (Fig. 5). Not all areas had such dramatic increases. Maine and Newfoundland began an increase in the early-1970s but remained within historical range in the early- and mid-1980s.

Between 1970 and 1986 landings in some areas have ranged from the lowest to the highest levels of

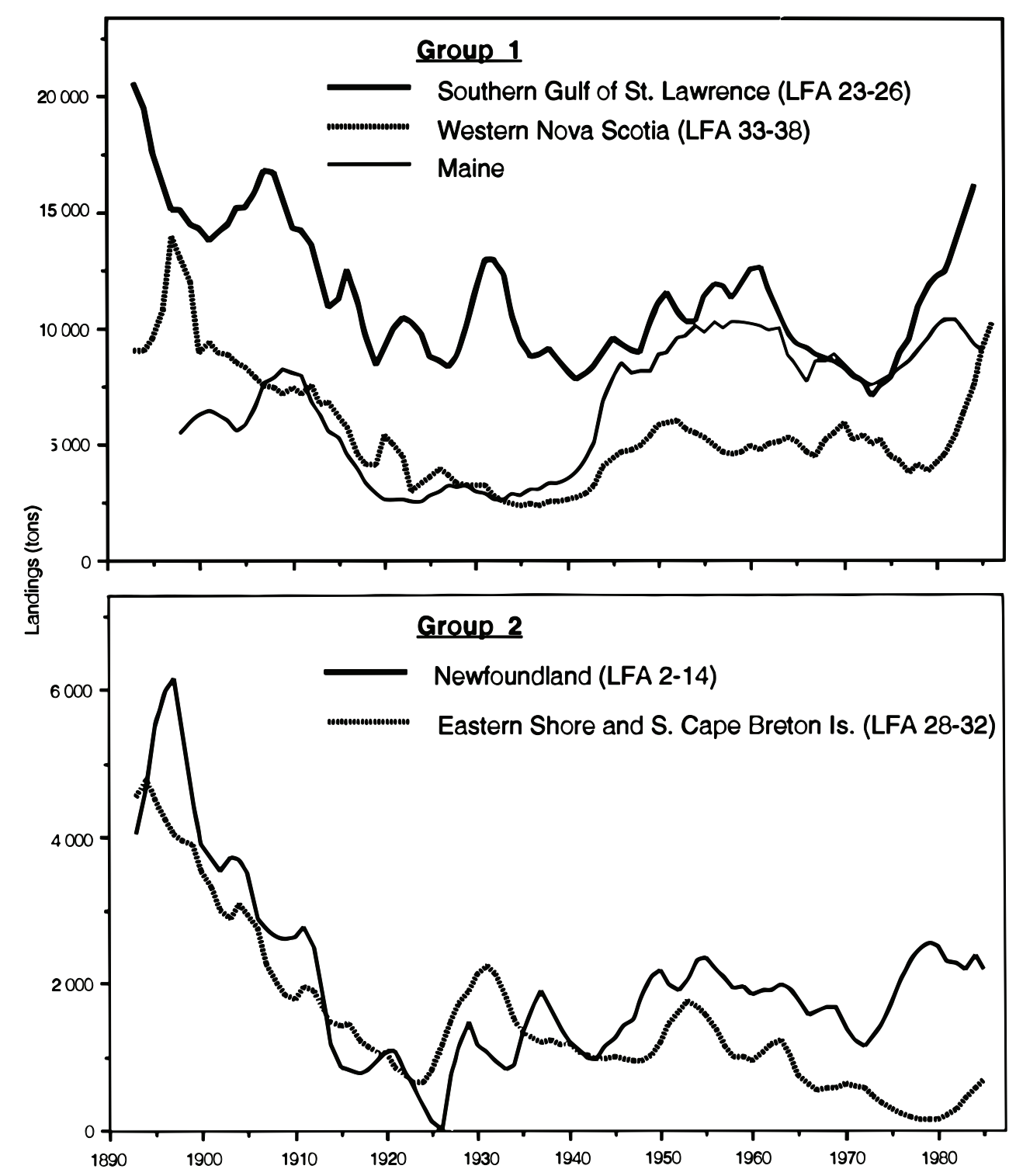

Fig. 4. Historical lobster landings data during 1893-1986 divided into Groups 1 and 2 based on trends. Data smoothed using 3-year moving average. 
the century, with the most recent increase being the largest and most sustained ever observed in the fishery. Though effort increased over the same period, so did the catch-per-unit-effort (C/E; kg/ trap haul) (Miller et al., MS 1987) which indicates an increase in abundance due to increased recruitment.

The recruitment pulse was evident in size frequency data from the at-sea sampling of the commercial catch at the beginning of the fall season in LFA 34. There was an increase in the number of prerecruits within one molt increment of the legal size (Molt Group 0), between 1978 and 1987 (as indicated by the increase in the C/E of prerecruits; Fig. 6).

Lobsters have discrete growth increments and periods. Growth occurs when they shed the old exoskeleton during molting. Lobsters close to legal size molt once annually during the summer or early autumn During each molt they increase by an average of $15 \%$ in carapace length (distance from the base of the eye to the anterior end of the carapace) and about $50 \%$ by weight (Aiken, 1980). Lobsters in Molt Group 0 molt the following summer into Molt Group 1, and are available to the fishery.

The increased prerecruits C/E over the period of increased landings (Fig. 7) supports the idea that the underlying cause of increased landings is an increase in recruitment. However, in LFA 34 and LFA 38 some of the increased landings can also be attributed to the expansion of fishing effort to less exploited grounds further from shore (Sharp and Duggan, 1985).

Landing trends during 1947-86 can be divided into two major groups (Fig. 8): Group 1 representing areas with stable landings over most of the period - Maine, Newfoundland, Grand Manan (Fig. 8a), LFA 34, LFA 33, LFA 35-36 (Fig. 8b), LFA 24-26, Quebec, LFA 27 and Massachusetts (Fig. 8c); and Group 2 representing areas with wider variations in landings - LFA 31-32 and LFA 28-30 (Fig. 8d). Group 1, with stable landings, can be subdivided into the cold water areas, the Gulf of Maine (Fig. $8 a, b)$ and warm water areas, the Gulf of St. Lawrence (Fig. 8c). Harding et al. (1983) examined landings (1920-80) using correlation analysis and found four major areas; the Gulf of St. Lawrence, the eastern shore of Nova Scotia, the Gulf of Maine and the States south of Cape Cod, Massachusetts. Campbell and Mohn (1983) using cluster analysis on landings from 1892-1981 found similar divisions and suggested three stock areas, Gulf of St. Lawrence, the Gulf of Maine and the eastern coast of Nova Scotia that appeared to be a transitional zone between the former two areas.

Group 1 accounts for approximately $80 \%$ of eastern North American lobster landings and has shown greater stability over the last 40 years. The ratio of the maximum and minimum landings (Max./ Min.) is an estimate of the magnitude of recruitment variability that can be expected within a stock (Rothschild, 1986). During the 40 year period, the Max./Min. ratios were low, ranging from 1.7 in Maine to 4.3 in LFA 27.

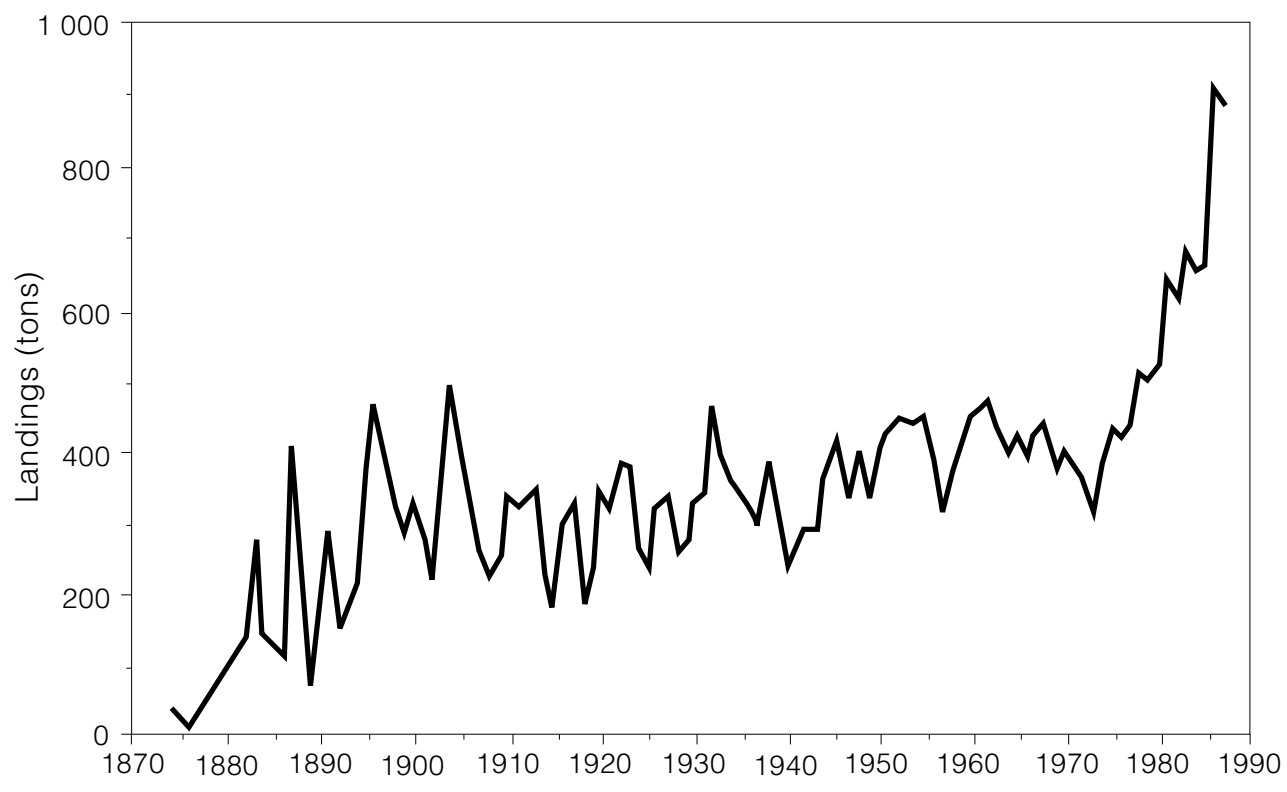

Fig. 5. Historical lobster landings for LFA 27 during 1873-1987. 


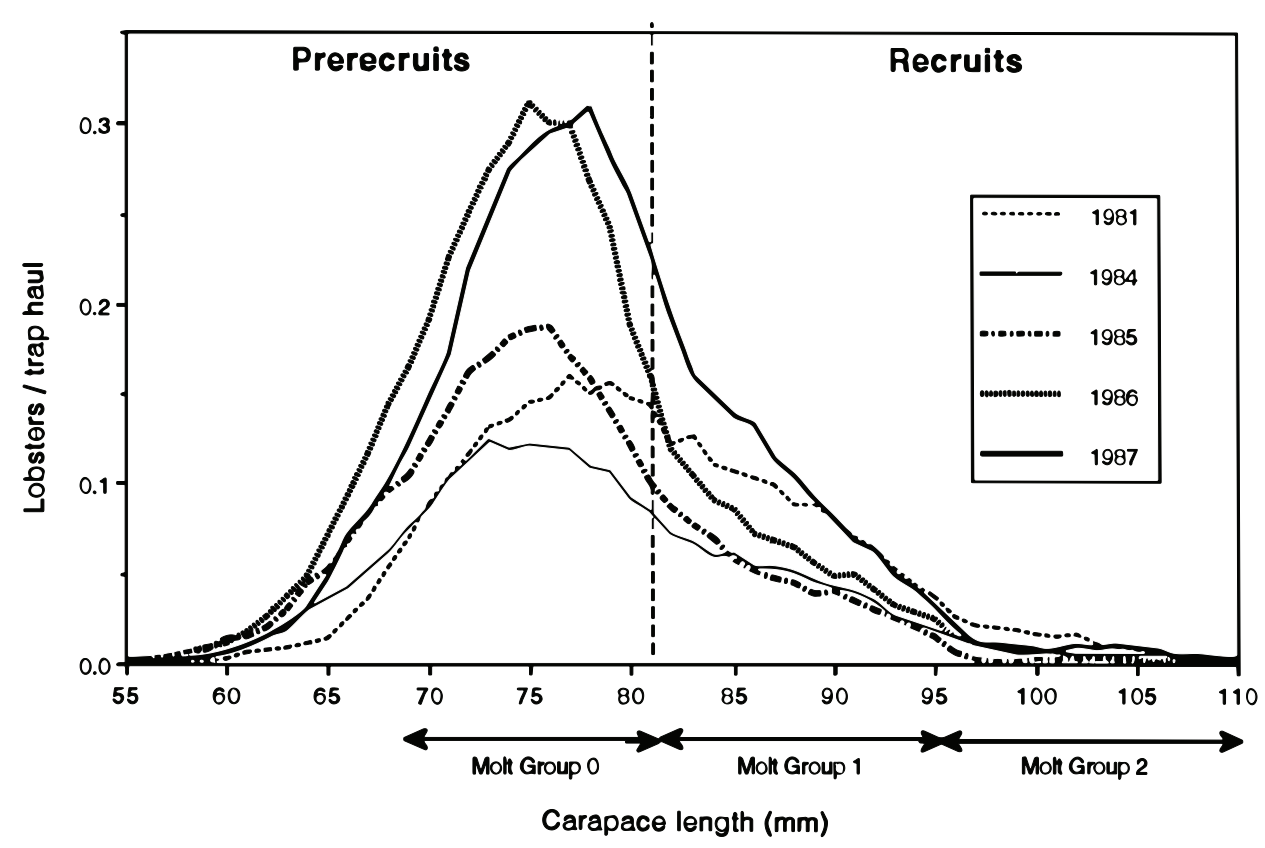

Fig. 6. Size frequency of lobsters in commercial catch in LFA 34. Samples were collected in December between 1981 and 1987.

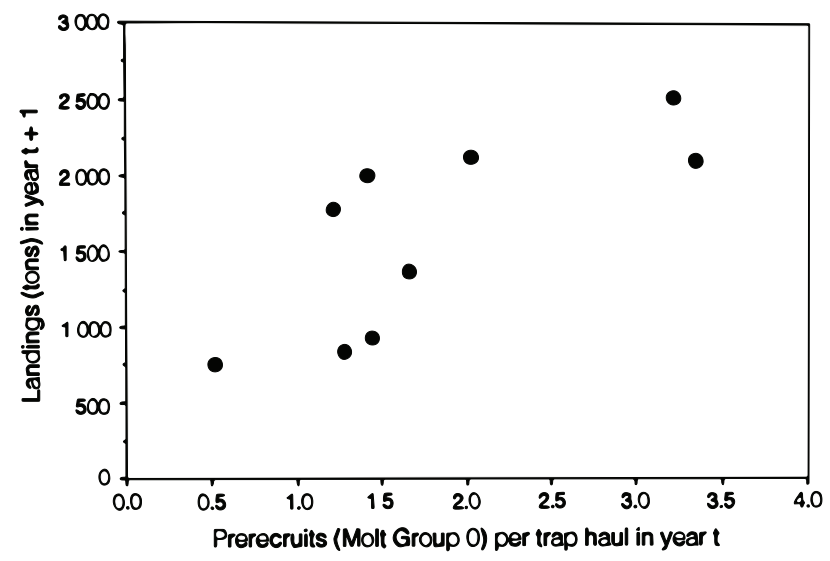

Fig. 7. Lobster landings plotted against catch-per-uniteffort of prerecruits (Molt Group 0) the previous year in LFA 34.

Within Group 1, Newfoundland, Maine and LFA 38 have had stable landings between 1947 and 1986. These experienced only a small decrease in the 1970s and the present catches are near the long-term mean. LFA 34 also showed stability between 1947 and 1980, with only a small downturn in the mid-1970s. However, since 1980 landings have increased steadily and in 1986 were at levels equivalent to the early-1900s. The adjacent grounds of LFA 33 and LFA 35-36 were also stable through the 1940s to mid-1960s then declined in the 1970s, with LFA 33 reaching record low landings in 1978. LFA 33 has shown the largest increase in landings of any area, increasing tenfold between 1981 and 1986. Landings in 1986 were equal to those of the early1900s. The LFA 35-36 landings increased during the late-1970s and early-1980s and in 1986 were the highest of the last 40 years.

The warm water areas within Group 1, the Gulf of St. Lawrence, LFA 27 and Massachusetts, showed similar patterns to the colder water areas, though the timing differed. The large LFA 24-26 fishery and the smaller Quebec and LFA 27 fisheries were stable through the 1950s but declined in the early-1960s. The upturn in landings began in the mid-1970s at a time similar to Newfoundland but approximately 56 years earlier than LFA 33 and 34. Southern Gulf of St. Lawrence landings increased to record high levels in the mid-1980s. Massachusetts landings were very stable over the $1947-75$ period then increased to all time highs in the 1980s. A portion of this increase was the result of improved reporting of landings, effort and expansion of grounds, but increases in C/E suggest a real increase in abundance had also occurred (B. T. Estrella, Massachusetts Division of Marine Fisheries, USA, pers. comm.).

Areas in Group 2, with more variable landings, include LFA 31-32 and LFA 28-30 (Fig.8). The Max./Min. ratio ranged from 12.3 in LFA 31-32 to 23.0 for LFA 30, 3-5 times greater than the largest observed in Group 1. Landings peaked in the midto late-1950s (depending upon LFA), followed by a long period of declining landings that reached a low 


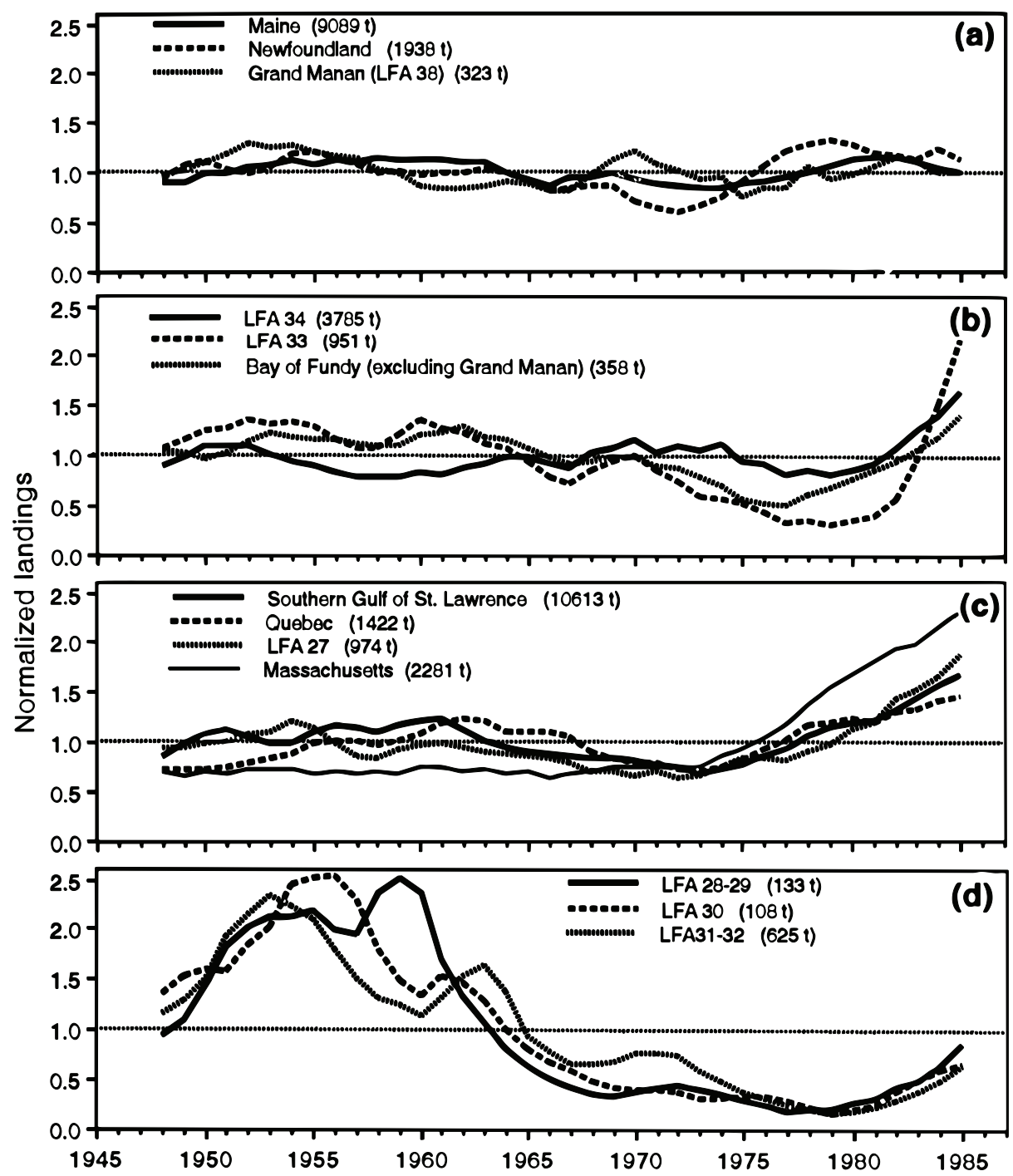

Fig. 8. Normalized landings 1947-85, with mean landings for the 1947-85 period in parenthesis. Areas grouped by common pattern in landings (a) Maine, Newfoundland and Grand Manan (LFA 38); (b) LFA 34, LFA 33 and the Bay of Fundy (excluding Grand Manan); (c) Southern Gulf of St. Lawrence, Quebec, LFA 27 and Massachusetts; (d) LFA 28-29, LFA 30 and LFA 31-32.

between 1976-80. Landings increased during the early-1980s, and though in LFA 28-32 they increased five-fold since 1980, landings were still well below those of the 1950s.

In summary, all lobster fishing areas showed increased landings during the 1940s and 1950s, a decline during the 1960s and an increase in the late-1970s and early-1980s. The magnitudes and timing of the increases differ, being observed earlier in the warmer water areas (LFA 24-26 and Massachusetts). Areas outside the major concentrations in the LFA 24-26 and LFA 34 experienced the largest increases as well as the largest de- clines. Three areas, Maine, LFA 38 and Newfoundland, have not experienced the same increase in the early-and mid-1980s as other areas.

\section{Stock-recruitment relationships}

Increased landings accompanied by increased C/E (Miller et al., MS 1987) and increased abundance of prerecruits suggests a recruitment pulse has occurred. Understanding the factors controlling recruitment is important in determining management measures to maximize the returns from the fishery. The belief in a stock recruitment relationship is the basis of much of the lobster management 
system. The decline in landings during the 1960s was blamed in part on recruitment over-fishing (Robinson, 1979), and it was recommended that the minimum size be increased to increase egg production. Though no size increase occurred, the fishery recovered to near record high levels. The higher landings of the 1980s are based on newly recruited lobsters that hatched and settled to the bottom 6-8 years previously, when the landings, and by inference standing stock, were at their lowest. The scale of the recent increase has renewed interest in the question of a stock recruitment relationship and the important variables in determining population size.

Stock-recruitment relationships for lobster populations are not known. The relationship is likely complex and highly variable (Sissenwine, 1984), since lobsters have a complex life cycle (Wilbur, 1980) with several life history stages with different ecological characteristics. The female carries the eggs externally for 10 months, and once hatched there are four planktonic larval stages that show stage differentiated depth distributions (Harding et al., 1987). The early benthic stages are cryptic, living in burrows, while larger juveniles begin to feed outside the burrows and the large mature animals become less dependent on the need for shelter. Each stage will respond differently to changes in the different physical and biological variables they are exposed to.

Fogarty and Idoine (1986) presented evidence for density dependent relationships in the early benthic stages. Using a multi-stage model they describe an asymptotic relationship between the numbers in the final larval stage and subsequent recruitment, which results in a stable population that is resilient to exploitation. Paulik (1973) illustrated the complexity of stock recruitment curves in animals with complex life histories. He illustrated the potential of multiple equilibrium and the importance of the initial conditions of the stock on the equilibrium point.

Stock recruitment relationships are not constant but vary with environmental conditions and local habitat. There are likely many variables and interaction of variables affecting recruitment. The variables will vary on different time scales, making the job of quantifying the relationships difficult.

\section{Causes of the recent recruitment pulse}

Environmental changes. Environmental variables can act over large areas and could explain the widespread nature of the recent increase in landings (Koslow, 1984; Koslow et al., 1986; Sinclair et al., 1986) that have occurred in different stocks (Campbell and Mohn, 1983) and management re- gimes. While both environmental factors and interactions between species are likely to produce similar effects on several stocks within a particular area, only large-scale environmental factors are likely to produce similar effects on stocks from different areas (Shepherd et al., 1984).

Temperature is often examined to relate recruitment to environment change, but the relationship between temperature and the biology and physiology of the organism is complex. Temperature affects the lobsters at all life history stages (Aiken and Waddy, 1986) controlling growth, size of maturity, timing of spawning and egg hatching, duration of egg development, condition of larvae at hatching (energy reserves), duration of larval stages, and adult migration patterns (Campbell, 1986; Uzmann et al., 1977). Temperature can also affect the general ocean productivity, affecting the food supply and the numbers of predators or competing species, for both planktonic and benthic stages.

In looking for relationships between temperature and landings, the appropriate measures of temperature must be used. Surface temperature directly affects larval stages while bottom temperature acts on the juvenile and adult stages. Temperatures are also often expressed as mean annual temperature (Dow, 1977; Orach-Meza and Saila, 1978), mean monthly temperature (Fogarty, 1988), or mean temperature over a portion of the year (Flowers and Saila, 1972). Other useful measures may be total degree days, duration above a set temperature, maximum or minimum temperatures, or temperature during a critical period.

The relationships between temperature and landings are unlikely to be linear but rather a complex nonlinear function of population size, age structure and temperature at critical periods in each stage. In nonlinear and complex systems, small changes can have large effects and the effect can vary with the initial state of the system (Rothschild, 1986), such that repeating the temperature conditions may not result in the same effect if other variables have changed.

Lobster currently being landed were hatched during a period of warm coastal water temperatures (Fig. 9) that began in the mid-1970s (Drinkwater and Trites, 1987; 1988; Mountain, 1982). Water temperatures during the mid-1970s, were below those of the early-1950s, a period of lower lobster abundance. This suggests that though temperature plays a role in recruitment success, the relationship is neither simple, nor is it likely that temperature is the sole factor. 
Studies relating temperature to landings show the importance of water temperatures approximately 6 years earlier (Dow, 1977; 1978; Flowers and Saila, 1972; Fogarty, 1988; Orach-Meza and Saila, 1978). Since the time to grow to legal size in the areas studied is estimated at $5-7$ years, biologists believe that temperature acts on the larval or early juvenile period. Landings in the Gulf of Maine have shown significant correlation with surface temperatures (Dow, 1977; 1978; Harding et al., 1983), but Harding et al. (1983) found no similar correlation along the eastern coast of Nova Scotia.

A second environmental variable that has been related to lobster abundance is the outflow from the St. Lawrence River. Quebec lobster landings in the northern Gulf of St. Lawrence have been correlated with freshwater runoff of St. Lawrence River (Sutcliffe, 1973). A significant correlation was found between lobster landings and river runoff 9 years earlier and the correlation held into the early-1980s (Drinkwater, 1987). Though the correlations were significant, a mechanism and the biological basis for the relationship is unknown. The best estimate of lobster ageat-capture in the area concerned is 5-6 years, meaning that the effect of river runoff would have to be acting on the parent stock 2-3 years before the larvae are produced. Other studies have questioned the importance of river runoff, and have suggested that climatic events in the ocean, forced by large scale atmospheric circulation may be the primary mechanism (Koslow, 1984; Koslow et al., 1986; Sinclair et al., 1986).

Environmental variability may explain the larger fluctuations in lobster landings along the eastern shore of Nova Scotia, than in the Gulf of Maine and Gulf of St. Lawrence. Dadswell (1979) suggested that the Gulf of St. Lawrence and southwestern Nova Scotia represented closed recruitment cells in which larval retention is maximized, while the eastern shores of Nova Scotia were open cells where larval retention was lower and more variable. The narrowness of available lobster habitat (Fig. 1), the lack of warm deep-water areas in the winter or high temperatures in the coastal region during the summer, may make the eastern shore of Nova Scotia a marginal habitat in some years and more susceptible to small changes in temperature. In contrast, the two more stable areas, southwestern Nova Scotia and Gulf of Maine region and the southern Gulf of St. Lawrence has either warm summer temperatures or access to areas of warm winter temperatures. The Gulf of Maine has a wide shelf area and direct access to deep-water that remains warm in the winter. Mature lobsters appear to migrate to these deeper areas, and it is believed they can maximize the temperature available to insure growth and egg development (Campbell, 1986; Pezzack and Duggan, 1986). The southern Gulf of St. Lawrence also has a wide expanse of shallow water that, although freezing occurs over in the winter, warms quickly and has the warmest temperatures on the Canadian east coast in summer.

Changes in the marine ecosystem. Ecosystem changes can result from environmental changes or from human activities. Recent changes that have been attributed to man's activities are a reduction of lobster predators, through overfishing of groundfish, changes in water movements resulting from the construction of the Canso Causeway in the mid-

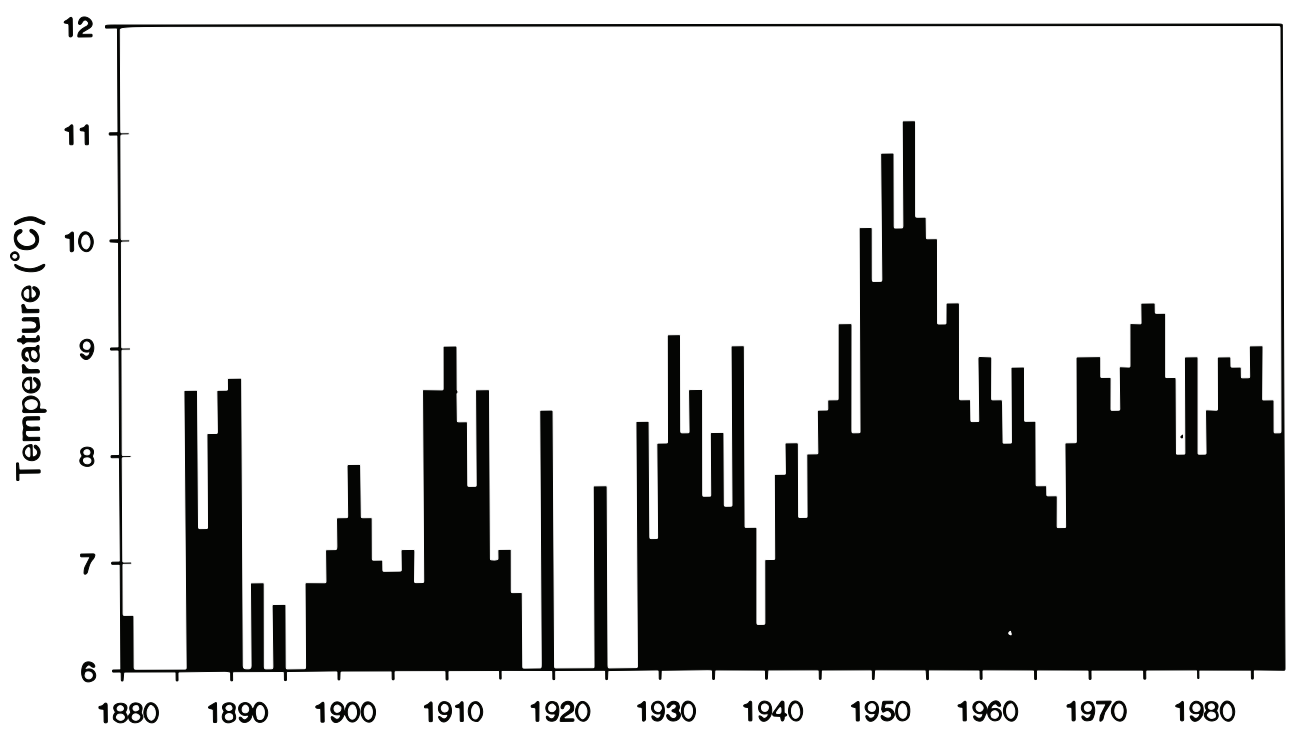

Fig. 9. Mean annual sea surface temperature (Calculated from mean monthly data) from Boothbay Harbor, Maine, between 1880 and 1986 (J. S. Krouse, pers. comm.) 
1950s (Dadswell, 1979; Harding et al., 1983) and the increase in the abundance of sea urchins and disappearance of kelp beds during the 1970s as a result of overfishing (Breen and Mann, 1976).

Heavy exploitation of groundfish species, which are potential predators on juvenile and immature lobsters, has been proposed as a potential cause of the recent increases in lobster abundance. Fogarty and Idoine (1986) suggest the early benthic stages may be important in determining recruitment levels. Brander and Bennett (1986) have shown a relationship between cod abundance and stock size of the Norwegian lobster (Nephrops norvegicus) in the Irish Sea.

A review of literature on groundfish feeding did not show evidence of major predation on lobsters (Bowman, 1981; Bowman et al., MS 1976; Bowman and Michaels, MS 1984; Edwards and Bowman, 1979; Homans and Needler, 1946; Langton, 1982; Langton and Bowman, 1980; Robichaud et al., 1991; Templeman, 1985). However, most of the feeding studies were offshore and did not represent inshore juvenile lobster habitat. Predation studies along the coast of Maine found that two abundant noncommercial species, cunners (Barshaw and Lavalli, 1988) and sculpins were major predators on juvenile lobsters. In the same study few lobsters were found in the stomachs of cod, haddock or pollock (Ojeda, MS 1987). Further studies are required to determine the importance of predators in determining abundance of lobsters.

Two popular hypotheses to explain the decline of lobsters along the eastern and southern shore of Nova Scotia in the 1960s and 1970s, involved the Canso Causeway (Dadswell, 1979; Harding et al., 1983) and the decline of kelp (Breen and Mann, 1976; Mann, 1977). In each case details of the hypotheses and the assumptions on which they were based have not stood up to testing (Elner and Vadas, 1990). The conclusions of a special workshop to study the effects of the Causeway on fisheries concluded that the Causeway was not the cause of the downturn in lobster landings along the coast, though it may have had some local effect (McCracken, 1979). Reviews of the evidence against the hypothesized relationship between kelp and lobster have also been presented (Elner and Vadas, 1990; Miller, 1985; Scheibling and Stephenson, 1984). Neither hypothesis could explain the wide scale nature of the changes in landings both during the decline and the subsequent recovery. At most they could explain only small scale local effects.

The fishery and fishery management. Changes in abundance due to fishing activity or natural fluctuations induced by environmental or ecological changes are often difficult to separate (Rothschild, 1986). The environment ultimately determines the production of the species, but the fishery is the major source of adult mortality that is important in determining population size structure and spawning biomass in lobsters. The fishery removes $60-90 \%$ of the lobsters in the first year of legal size. In most areas few reach maturity, which is expected to occur 1-3 years after recruitment to the fishery.

Changes in exploitation rates can affect egg production in subsequent years, but to date no clear stock recruitment relationship has been found in lobsters. There is likely a critical spawning biomass below which fishing pressure becomes an important factor in the interannual variability (Wooster, 1983). At these low levels, recruitment becomes more vulnerable to environmental factors and the potential for collapse increases.

There is no conclusive evidence that the critical levels have been reached in the American lobster fisheries. The widespread nature of the downturn in the 1960s and the recent increases in different stocks (Campbell and Mohn, MS 1982; 1983), with different exploitation rates, suggests that natural fluctuations triggered by environmental variables underlie the recent fluctuations in lobster abundance. The influence of fishing on the magnitude of these fluctuations is an important question for managers who seek to dampen the major downturns in the fishery.

Canadian management measures introduced in the late-1970s, such as trap limits and reduction in the number of licenses, have reduced the potential effort that could be applied to the recovering stocks. However, effective effort has increased. Improved navigation, vessel and gear designs allow fishermen to fish more days, haul more gear per day and fish new grounds further from shore. Fishing effort responds to lobster abundance with latent effort available during periods of low abundance (Pringle and Duggan, MS 1984). Though the management measures of the late-1970s are not the cause of the increased landings, they have put an upper limit on effort that may help in sustaining both the recovery and higher landings in the future.

\section{Conclusions}

Common landing trends have occurred over large areas. The major increases in the 1940-50s and 1970-80s and the decreases of the 1960-70s occurred in all areas, though the exact timing and magnitude of the changes are not the same in all areas. The faster growth rate and smaller minimum legal size in the Gulf of St. Lawrence meant that the recruitment pulse was detected earlier there than in 
colder water areas. The age-at-recruitment is believed to be 5-6 years in the southern Gulf of St. Lawrence, but 6-8 years on the Atlantic coast of Nova Scotia (Aiken, 1980; Wilder, 1953).

The recruitment pulse of the late-1970s and early-1980s has resulted in the largest increase in the 100 years of recorded Canadian landings (Fig. 2 ). The increased landings are evident in all lobster areas, though the greatest increases have been observed in LFA 27, 33 and 34, LFA 24-26 and in Massachusetts. The smallest changes were in Maine and Newfoundland, which after an initial increase in landings during the late-1970s, have increased little and even showed a small decline.

The widespread nature of the increase suggests an environmental change as a major causal factor. Changes in water temperatures are a possible mechanism to explain the variations in recruitment levels. The relationship between environment and population variability in a complex and nonlinear system will be difficult to quantify, since small environmental changes may have no effects or delayed effects, and not always the same effects, if other variables in the system have changed (Rothschild, 1986).

Variations in the timing and magnitude of the fluctuations in landings are functions of the initial stock biomass and population size structure, local exploitation rates, potential fishing effort and the lag periods for changes in these variables, local environmental differences and the initial state of the variable(s) that trigger the change in recruitment levels. The multitude of variables makes it difficult to relate the recruitment pulse to a single controlling or triggering factor. A detailed knowledge of the local lobster biology and fishery would be required since the same environmental or man-made changes may result in different responses in different areas. Looking for a single mechanism or attempting to understand lobster recruitment cycles without knowledge of how environmental and biological variables interact could be misleading and unrewarding (Shepherd et al., 1984; Sissenwine, 1984; Walters and Collie, 1988).

The present increase in landings may be a short-term explosion that will pass or a new equilibrium may be reached and landings sustained at a higher level. The unprecedented nature of the recent increases and our lack of knowledge on stock recruitment relationships makes it impossible to use the historical data as a guide to future events.

\section{Acknowledgements}

I thank Anne Williamson who compiled the historic landings data, and J. Idoine, M.J. Fogarty, M.J.
Tremblay and J.C. Pringle for comments on earlier versions of this paper.

\section{References}

AIKEN, D. E. 1980. Molting and growth. In: The biology and management of lobsters. Vol. 1 (p. 91163). J.S. Cobb and B.F. Phillips (eds.). Academic Press, New York, N.Y.

AIKEN, D. E., and S. L. WADDY. 1986. Environmental influence on recruitment of the American lobster, Homarus americanus: A perspective. Can. J. Fish. Aquat. Sci., 43: 2258-2270.

ANTHONY, V. C. 1980. Review of lobster mortality estimates in the United States.. Can. Tech. Rep. Fish. Aquat. Sci., 932: 17-25.

BARSHAW, D. E., and K. L. LAVALLI. 1988. Predation upon postlarval lobster Homarus americanus by cunners Tautogolabrus adspersus and mud crabs Neopanopi sayi on three different substrates: Eelgrass, mud and rocks. Mar. Ecol. Prog. Ser., 48: 119123.

BOWMAN, R. E. 1981. Food of 10 species of northwest Atlantic juvenile groundfish. Fish. Bull. U.S., 79: 200-206.

BOWMAN, R. E., R. O. J. MAURER, and J. A. MURPHEY. MS 1976. Stomach contents of 29 fish species from 5 regions in the Northwest Atlantic. Data Rep. NMFS (U.S.), 76-10: $37 \mathrm{p}$.

BOWMAN, R. E., and W. L. MICHAELS. MS 1984. Food of seventeen species of Northwest Atlantic Fish. NOAA Tech. Mem., NMFS-F/NEC-28, $183 \mathrm{p}$.

BRANDER, K., and D. B. BENNETT. 1986. Interactions between Norway lobster (Nephrops norvegicus) and cod (Gadus morhua) and their fisheries in the Irish Sea. Can. Spec. Publ. Fish. Aquat. Sci., 92: 269-81.

BREEN, P. A., and K. H. MANN. 1976. Changing lobster abundance and destruction of kelp beds by sea urchins. Mar. Biol., 34: 137-142.

CAMPBELL, A. 1980. A review of mortality estimates of lobster populations in the Canadian Maritimes. Can. Tech. Rep. Fish. Aquat. Sci., 932: 27-35.

1986. Migratory movements of ovigerous lobsters, Homarus americanus, tagged off Grand Manan, Canada. Can. J. Fish. Aquat. Sci., 43: 2197-2205.

CAMPBELL, A., and R. K. MOHN. MS 1982. The quest for lobster stock boundaries in the Canadian Maritimes. NAFO SCR. Doc., No. 107, Serial No. N615: 45 p.

CAMPBELL, A., AND R. K. MOHN. 1983. Definition of American lobster stocks for the Canadian Maritimes by analysis of the fishery landing trends. Trans. Amer. Fish. Soc., 112: 744-759.

DADSWELL, M. J. 1979. A review of the decline in lobster (Homarus americanus) landings in Chedabucto Bay between 1956 and 1977 with an hypothesis for a possible effect by the Canso Causeway on the recruitment mechanism of eastern Nova Scotia lobsters stocks. Fish. Mar. Serv. Tech. Rep., 834 (Part 3): 113-144.

DEWOLF, A. G. 1974. The lobster fishery of the maritime provinces: economic effects of regulations. Bull. Fish. Res. Board Can., 187: 59 p.

DOW, R. L. 1977. Relationship of sea surface temperature to American and European lobster landings. ICES J. Cons., 37: 186-190. 
1978. Effects of sea surface temperature cycles on landings of American, European and Norway lobsters. ICES J.Cons., 38(2): 271-272.

1980. The Clawed Lobster Fisheries. In: The biology and management of lobsters. Vol. 2 (p.265316). J.S. Cobb and B.F. Phillips (eds.). Academic Press, New York, N.Y.

DRINKWATER, K. F. 1987. "Sutcliffe revisited": Previously published correlations between fish stocks and environmental indices and their recent performance. Can. Tech. Rept. Fish. Aquat. Sci., 1556: 41-56.

DRINKWATER, K. F., and R. W. TRITES. 1987. An overview of environmental conditions in the Northwest Atlantic in 1985. NAFO Sci. Coun. Studies, 11: 23-36.

1988. An overview of environmental conditions in the Northwest Atlantic in 1986. NAFO Sci. Coun. Studies, 12: 43-56.

DUGGAN, R. E. 1985. Characteristics of the lobster fishery on the oceanic coast of Nova Scotia. Can. Man. Rept. Fish. and Aquat. Sci., 1883: $37 \mathrm{p}$

EDWARDS, R. L., and R. E. BOWMAN. 1979. Food consumed by continental shelf fishes. In: Predationprey systems in fisheries management (p. 1199-1217). H. Clepper (ed.). Sport Fish. Inst., Washington, D. C.

ELNER, R. W., and R. L. VADAS. 1990. Inference in ecology: The sea Urchin phenomenon in the Northwestern Atlantic. Amer. Nat., 136(1): 108-125.

ENNIS, G. P. 1986. Stock definition, recruitment variability, and larval recruitment processes in the North American lobster Homarus americanus: a review. Can. J. Fish. Aquat. Sci., 43: 2072-2084.

ENNIS, G. P., and W. R. SQUIRES. 1986. Fisheries and population biology of lobsters (Homarus americanus) at Arnold's Cove, Newfoundland. Can. Tech. Rep. Fish. Aquat. Sci., 1438: $34 \mathrm{p}$.

FLOWERS, J. M., and S. B. SAILA. 1972. An analysis of temperature effects on the inshore lobster fishery. J. Fish. Res. Board Can., 29: 1221-1225.

FOGARTY, M. J. 1988. Time series models of the Maine lobster fishery: the effect of temperature. Can. J. Fish. Aquat. Sci., 45: 1145-1153.

FOGARTY, M. J., and J. S. IDOINE. 1986. Recruitment dynamics in an American lobster (Homarus americanus) population. Can. J. Fish. Aquat. Sci., 43: 2368-2376.

HARDING, G. C., K. F. DRINKWATER, and W. P. VASS. 1983. Factors influencing the size of lobster stocks along the Atlantic coast of Nova Scotia, Gulf of St. Lawrence and Gulf of Maine: A new synthesis. Can. J. Fish. Aquat. Sci., 40: 168-184.

HARDING, G. C., J. D. PRINGLE, W. P. VASS, and S. J. PEARRE. 1987. Vertical distribution and diel movements of larval Homarus americanus over Browns Bank, Nova Scotia. Mar. Ecol. Prog. Ser., 41: 29-41.

HOMANS, R. E. S., and A. W. H. NEEDLER. 1946. Food of the haddock. Proc. N. S. Inst. Sci., 21: 15-49.

KOSLOW, J. A. 1984. Recruitment patterns in northwest Atlantic fish stocks. Can. J. Fish. Aquat. Sci., 41: 1722-1729.

KOSLOW, J. A., R. LOUCKS, K. R. THOMPSON, and R. TRITES. 1986. Relationships of St. Lawrence River outflow with sea surface temperature and salinity in the Northwest Atlantic. In: The role of freshwater outflow in coastal ecosystems (p. 271-282). S. Skreslet (ed.). NATO ASI Series, Vol. G7. SpringerVerlag, Berlin

LANGTON, R. W. 1982. Diet overlap between Atlantic cod, Gadus morhua, silver hake, Merluccius bilinearis, and fifteen other Northwest Atlantic finfish. Fish. Bull. U.S., 80: 745-759.

LANGTON, R. W., and R. E. BOWMAN. 1980. Food of 15 Northwest Atlantic gadiform fishes. NOAA Tech. Rep., NMFS SSRF-740, 23 p.

MANN, K. H. 1977. Destruction of kelp beds by sea urchins: A cyclical phenomenon or irreversible degradation. Helgol. Wiss. Meeresunters., 30: 455-467.

MCCRACKEN, F. D. 1979. Executive summary, Canso marine environment workshop. In: Canso marine environment workshop. Fish. and Mar. Serv. Tech. Rep., 834 (Part 1): 1-3.

MILLER, R. J. 1985. Seaweeds, sea urchins, and lobsters: a reappraisal. Can. J. Fish. Aquat. Sci., 42: 2061-2072.

MILLER, R. J., D. S. MOORE, and J. D. PRINGLE. MS 1987. Overview of the Inshore Lobster Resources in the Scotia-Fundy Region. CAFSAC Res. Doc., No. 85, $20 \mathrm{p}$.

MOUNTAIN, D. G. 1982. Oceanographic conditions in NAFO Subareas 5 and 6 during 1970-79. NAFO Sci. Coun. Studies, 5: 95-100.

OJEDA, F. P. MS 1987. Rocky subtidal community structure in the Gulf of Maine: The role of mobile predators. Ph. D. Thesis, University of Maine.

ORACH-MEZA, F. L., and S. B. SAILA. 1978. Application of a polynomial distributed lag model to the Maine lobster fishery. Trans. Amer. Fish. Soc., 107: 402411.

PAULIK, G. J. 1973. Studies of the possible form of the stock-recruitment curve. ICES Rapp. Proc.-Verb., 164: 302-315.

PEZZACK, D. S., and D. R. DUGGAN. 1986. Evidence of migration and homing of lobsters (Homarus americanus) on the Scotian Shelf. Can. J. Fish. Aquat. Sci., 43: 2206-2211.

MS 1987. Canadian Offshore Lobster Fishery, 1985-86, and assessment of the potential for future increases in catch. CAFSAC Res. Doc., No. 79, 25 p.

PRINGLE, J. D., and R. DUGGAN. MS 1984. Latent lobster fishing effort along Nova Scotia's Atlantic coast. CAFSAC Res. Doc., No. 59, 21 p.

ROBICHAUD, D. A., R. W. ELNER, and R. F. J. BAILEY. 1991. Differential selection of crab (Chionoecetes opilio and Hyas spp.) as prey by sympatric cod (Gadus morhua) and thorny skate (Raja radiata). Fish. Bull. U.S., 89: 669-680.

ROBINSON, D. G. 1979. Consideration of lobster (Homarus americanus) recruitment overfishing hypothesis; with special reference to the Canso Causeway. Fish. Mar. Serv. Tech. Rep., 834 (Part 3): 77-99.

ROTHSCHILD, B. J. 1986. Dynamics of Marine Fish Populations. Harvard Press, Cambridge. 277 p.

SCHEIBLING, R. E., and R. L. STEPHENSON. 1984. Mass mortality of Strongylocentrotus droebachiensis (Echinodermata: Echinoidia) of Nova Scotia, Canada. Mar. Biol., 78: 153-164.

SHARP, G. J., and R. E. DUGGAN. 1985. An aerial survey of near-shore and mid-shore lobster fishing distribution off southwestern Nova Scotia, spring and fall 1983-84. Can. MS Rep. Fish. Aquat. Sci., 1847: 37.

SHEPHERD, J. G., J. G. POPE, and R. D. COUSENS. 1984. Variations in fish stocks and hypothesis concerning their links with climate. ICES Rapp. Proc.-Verb., 185: 225-267.

SINCLAIR, M., G. L. BUGDEN, C. L. TANG, J.-C. 
THERRIAULT, and P. A. YEATS. 1986. Assessment of effects of freshwater runoff variability on fisheries production in coastal waters- the Gulf of St. Lawrence example. In: The role of freshwater outflow in coastal ecosystems (p.139-160). S. Skreslet (ed.). NATO ASI Series, Vol. G7. Springer-Verlag, Berlin.

SISSENWINE, M. P., Ed. 1984. Why do fish populations vary? Exploitation of Marine Communities. SpringerVerlag, Berlin.

SUTCLIFFE, W. H. J. 1973. Correlations between seasonal river discharge and local landings of American lobster (Homarus americanus) and Atlantic halibut (Hippoglossus hippoglossus) in the Gulf of St. Lawrence. J. Fish. Res. Board Can., 30: 856-859.

TEMPLEMAN, W. 1985. Stomach contents of Atlantic wolffish (Anarhichas lupus) from the Northwest Atlantic. NAFO Sci. Coun. Studies, 8: 49-51.

UZMANN, J. R., R. A. COOPER, and K. J. PECCI. 1977. Migration and dispersion of tagged American lobsters, Homarus americanus, on the southern New
England continental shelf. NOAA Tech. Rep., NMFS SSRF-705, $92 \mathrm{p}$.

VENNING, W. H. 1873. Annual report of the Department of Marine and Fisheries. Append. N.

1893. Report on the lobster industry of Canada, 1992. Vol. 9. Suppl. Queen's Printer, Ottawa.

WALTERS, C. J., and J. S. COLLIE. 1988. Is research on environmental factors useful to fisheries management? Can. J. Fish. Aquat. Sci., 45: 1848-1854.

WILBUR, H. M. 1980. Complex life cycles. Annu. Rev. Ecol. Syst., 11: 67-93.

WILDER, D. G. 1953. The growth rate of the American lobster (Homarus americanus). J.Fish. Res. Board Can., 10: 371-412.

WOOSTER, W. S. 1983. On the determinants of stock abundance. In: From year to year, interannual variability of the environment and fisheries of the Gulf of Alaska and the eastern Bering Sea (p.1-10). W.S. Wooster (ed.). A Washington Sea Grant Publication, Seattle. 
